\title{
Carbon Reduction Intentions and Behaviours for Sustainability
}

\author{
Jane Lu Hsu ${ }^{1} \&$ Ting-Yu Lin ${ }^{1}$ \\ ${ }^{1}$ Department of Marketing, National Chung Hsing University, Taichung, Taiwan \\ Correspondence: Jane Lu Hsu, Department of Marketing, National Chung Hsing University, 250 Kuo Kuang \\ Road, Taichung 40227, Taiwan. Tel: 886-4-2285-6376. E-mail: jlu@dragon.nchu.edu.tw
}

\author{
Received: September 26, 2013 Accepted: October 16, 2013 Online Published: November 5, 2013 \\ doi:10.5539/jsd.v6n12p1 \\ URL: http://dx.doi.org/10.5539/jsd.v6n12p1
}

\begin{abstract}
Increases in emissions of greenhouse gases resulted in rising global average temperature in the past few decades. In Taiwan, annual emissions of $\mathrm{CO}_{2}$ increased from 114.4 million tons in 1990 to 270.2 million tons in 2010, a staggering $136.2 \%$ increase in two decades. Strategic implementation of carbon reduction and environmentally sustainability becomes a top priority for government administration in public education in Taiwan. This study aims to examine information search behaviour and to reveal how carbon reduction behaviours differ from intentions. Carbon reduction intentions related to what respondents thought they should be doing for environmental sustainability. Behaviours referred to actions respondents had taken in particular ways to reduce carbon emissions. A survey was administered using personal interviews in March, 2010, in Taipei, Taiwan. A stratified sampling was utilised in this study following gender and age distributions of the population between the ages of 20 to 59. Findings in this study revealed that people search different types of carbon reduction information via various media channels. For those who prefer technology and policy related carbon reduction information, they would be more likely to take actions than those who prefer practical carbon reduction information. Technology/policy information seekers would have carbon reduction behaviour similar to their intentions, especially in energy usage and shopping activities. Practical information seekers seem to have higher level of behavioural discrepancies in carbon reduction. Strategic implications based on findings in this study are suggested.
\end{abstract}

Keywords: carbon reduction, environmentally sustainable behaviour, behavioural discrepancies, information search

\section{Introduction}

Increases in emissions of greenhouse gases (GHGs) resulted in rising global average temperature in the past few decades (Intergovernmental Panel on Climate Change, 2007). From 1990 to 2010, annual emissions of $\mathrm{CO}_{2}$ in the world increased $44.4 \%$, from 20,974 million tons to 30,276 million tons. In Taiwan, annual emissions of $\mathrm{CO}_{2}$ increased from 114.4 million tons in 1990 to 270.2 million tons in 2010, a staggering $136.2 \%$ increase in two decades. Taiwan was next to Singapore and ranked the second highest among Asian countries in annual per capita $\mathrm{CO}_{2}$ emissions of 11.66 tons in 2010 (International Energy Agency [IEA], $\mathrm{CO}_{2}$ Emissions from Fuel Combustion Highlights, 2012). Strategic implementation of carbon reduction and environmentally sustainability becomes a top priority for government administration in public education.

Information of carbon reduction disseminated in media in an effort to encourage the general public to act in environmentally sustainable behaviours may only enhance consciousness of the concept, not behaviours. Pickett-Baker and Ozaki (2008) explained the 'value-action gap' which reflected the phenomenon that even though individuals concerned about the environmental sustainability, a gap between awareness and behaviour remained. In educating the general public, it is essential to build fundamental perceptions of environmental consciousness and importance of actions (Bord et al., 2000; Stamm et al., 2000).

Information plays an imperative role in strengthening concepts of environmental protection (Kalantari \& Asadi, 2010). Media exposure is necessary for the general public to learn factual knowledge and how to apply relevant knowledge (Chan, 1999; Nisbet et al., 2002). Mass media and communication were commonly used by the general public to obtain information related to environmental issues (Stamm et al., 2000). Robson and Robinson (2013) explained that information behaviour consisted of two parts, information seeking and communication. Information seeking would be actual searching for needed information, while communication could be done in 
various interactive ways. Individuals who received communications assessed the information, but whether communications could lead to actions depended on needs and motivations (Robson \& Robinson, 2013).

In science communication, mass media is a major source for the general public to learn and to form perceptions toward environmental issues. Arlt et al. (2011) indicated that media usage had influenced awareness and behavioural intentions in topics related to climate change. Nisbet et al. (2002) stated that for those who were no longer in the system of formal education, mass media would be accessible sources to acquire information in science communication. Hansen (2010) mentioned media as sources of information for informal learning regarding global warming and suggested to emphasise practical action as an important aspect in environmental issues. Tobler et al. (2012) also emphasised the importance of disseminating accurate information as well as action-related knowledge about climate change in the media to encourage individuals' engagement.

Arslan et al. (2012) explained that environmental attitude was an important factor influencing environmental consciousness. Environmental education for the public can enhance awareness of the issue and further encourage carbon reduction behaviours. Hence, disseminating information of carbon reduction through media in an effort to augment awareness and to enhance pro-environmental behaviours cannot be overemphasised.

Environmental behaviour has been a topic in understanding how individuals' actions influencing carbon emission reduction. Behavioural changes of individuals are pivotal for achieving sustainability (Sufiyan, 2013). Due to the severity of carbon emission issue in Taiwan and research gap in this matter, this study aims to examine information search behaviours and to reveal how carbon reduction behaviours differ from intentions. The contribution of this study is to provide a baseline for government agencies to enhance effectiveness of information dissemination in order to ease the intensity of this issue in the region.

\section{Method}

This study examines individuals' information search behaviours and how their carbon reduction behaviours differ from intentions. A questionnaire was designed and modified based on findings in the relevant literature (Whitmarsh \& O'Neill, 2010) and suggestions of in-depth interviews with 15 informants in the pilot study.

Three sections were included in the questionnaire. The first section measured respondents' information search. The second section was designed to reveal personal intentions of carbon reduction and actual behaviours in five different categories, food, transportation, energy usage, reuse/recycle, and shopping related activities. The third section was of demographics.

In relevant literature, Bravo et al. (2013) selected food, transportation, energy as three major categories in consumption for analysing impact of environmental behaviours. Tukker et al. (2006) examined a number of studies and concluded that food and drink, private transport, housing are three areas with the greatest impact on environmental sustainability. In this study, five categories, food, transportation, energy usage, reuse/recycle, and shopping activities, were considered in analysing carbon reduction intentions and behaviours based on findings in the literature and common practices of environmental behaviours in Taiwan.

\subsection{Carbon Reduction Information}

The information of carbon reduction was monitored and observed in the mass media from December 2009 to March 2010. Hundreds of pieces of carbon reduction information were collected, sorted and categorised into seven information types using content analysis: (1) practical ways of carbon reduction in daily lives; (2) new energy-saving products in the market; (3) per capita carbon emission volume; (4) carbon emissions from household appliances; (5) relevant carbon reduction activities; (6) theory and technology of carbon reduction; and (7) administrative policies of carbon reduction. Major references of various types of carbon reduction information are listed in Table A1.

\subsection{Carbon Reduction Intentions and Behaviours}

Two sets of statements were designed in the questionnaire to ask respondents about their carbon reduction intentions and behaviours (Table A2). In carbon reduction intention statements, ten questions were listed for five categories with two questions for each category. For food category, respondents were asked whether they thought that food should not be wasted, and whether they thought they should be eating more vegetables and less meat. For transportation category, respondents were asked whether they thought walking or cycling should be used to replace driving or riding motorcycles, and whether they would take public transportation if available. For energy usage, respondents were asked whether they thought they should turn off air conditioners more often and could open up windows to help air circulations, and whether they thought they should turn off power switch of unused appliances. For reuse/recycle, respondents were asked whether they thought reuse/recycle would be a must, and whether they thought they should use less disposable products (like disposable bamboo chopsticks and 
plastic utensils). For shopping activities, respondents were asked whether they thought they should purchase fewer clothes, and whether they should purchase appliances with certificates of energy efficiency. Six-point Likert scales (six-strongly agreed, one-strongly disagreed) were used to measure various levels of agreement in these statements.

In order to measure carbon reduction behaviours but not to duplicate questions of intentions, a set of different questions were designed in the questionnaire. Two questions per category were listed. For food category, respondents were asked if they had a dinner with friends in restaurants, whether they would order just about the right amount of food items instead of ordering more than enough. Another question in food category asked whether respondents could have at least one day a week without eating meat products. For transportation category, respondents were asked if the distance of a destination could be reached by foot or by bicycle, then they would choose not to drive or to ride motorcycles. Another question in transportation category asked respondents how they would be willing to take public transportations. For energy usage, respondents were asked when the room temperature was not above certain centigrade, they would not turn on air conditioners. Another energy usage question asked respondents whether they would turn off the light whenever they left the room. For reuse/recycle, respondents were asked if they had chosen rechargeable batteries, and whether they would carry personal chopsticks (like travel sets), water bottles or mugs, and reusable shopping bags with them. For shopping activities, respondents were asked if they would not shop for clothing as long as they had enough, and when they purchased appliances, they would choose those certified with energy efficiency labels. Carbon reduction behaviour questions were measured using frequency scales. Six scales were applied from never (one point), seldom (two points), occasionally (three points), sometimes (four points), often (five points), to always (six points).

Questions of carbon reduction intentions were designed to measure how respondents thought about reducing carbon emissions. Statements were using the word 'should' to seize the beliefs of respondents in carbon reduction intentions. Questions of carbon reduction behaviours were to measure how frequent respondents took actions in carbon reduction. Statements were more of descriptions in reality to reveal certain behaviours. If a respondent strongly agreed with one statement in carbon reduction intentions but seldom or never had taken actions, then there would be behavioural discrepancies.

\subsection{Demographics}

In demographics, respondents' gender, age, marital status, educational levels, occupation, monthly personal income, monthly household income and household size were questioned.

\subsection{Conceptual Framework}

The conceptual framework is illustrated in Figure 1. The aim of this study is to reveal discrepancies between intentions and behaviours in carbon reduction for environmental sustainability. The conceptual framework reveals that even though with all kinds of carbon reduction information respondents could have obtained, gaps of what people think they should be doing and what people actually take actions in carbon reduction exist. Individuals understand the importance of carbon reduction, but may not take all of the necessary steps in actions. Information of carbon reduction disseminated for public education has to reinforce the awareness and importance of actions taken in behavioural decisions. Only when individuals understand environmental behaviours, not intentions, are essential for sustainability, the severity of excess carbon emissions can be alleviated.

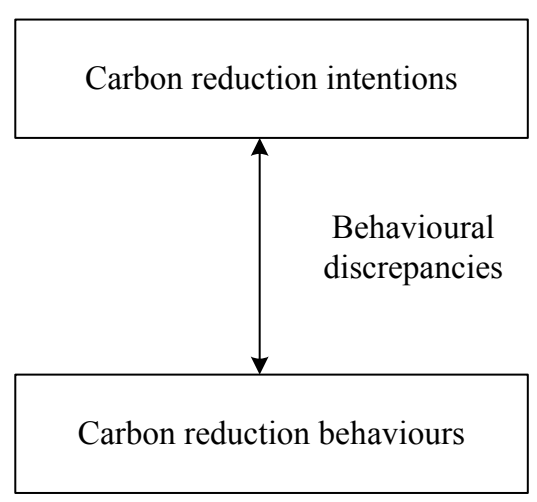

Figure 1. Conceptual framework of the study 


\subsection{Data Collection}

The formal survey was administered using personal interviews in March, 2010 in Taipei, Taiwan. A stratified sampling was utilised in this study following gender and age distributions of the population between the ages of 20 to 59 of the latest census in Taipei, Taiwan (Table 1). Trained interviewers would approach potential respondents in public areas and explained the purposes of the study in details. A gift worth of USD 2 was provided to each respondent who was willing to participate in the survey. Trained interviewers would provide assistance in explaining meanings of statements but not to interfere the way respondents answered the questions. It took approximately 20 to 30 minutes to finish the questionnaire. Those people who refused to participate in the survey were mainly due to personal time constraints. For those respondents who could not finish the survey, the questionnaire was discarded and the gift was not retrieved back. The total surveyed respondents were 300 . Males and females accounted for about half of the total respondents. The valid sample were 282, including 131 male samples and 151 female samples. Eighteen invalid samples were deleted due to incomplete answers.

Table 1. Gender and age distributions of samples and the census

\begin{tabular}{|c|c|c|c|c|c|c|c|c|}
\hline \multirow{3}{*}{ Age range } & \multicolumn{4}{|c|}{ Population in Taipei (census, by the end of February 2010) } & \multicolumn{4}{|c|}{ Valid samples } \\
\hline & \multicolumn{2}{|c|}{ Male } & \multicolumn{2}{|c|}{ Female } & \multicolumn{2}{|c|}{ Male } & \multicolumn{2}{|c|}{ Female } \\
\hline & Person & $\%$ & Person & $\%$ & Person & $\%$ & Person & $\%$ \\
\hline $20 \sim 39$ & 356,222 & $22.30 \%$ & 386,778 & $24.22 \%$ & 64 & $22.69 \%$ & 73 & $25.89 \%$ \\
\hline $40 \sim 59$ & 398,840 & $24.97 \%$ & 455,411 & $28.51 \%$ & 67 & $23.76 \%$ & 78 & $27.66 \%$ \\
\hline Total & 755,062 & $47.27 \%$ & 842,189 & $52.73 \%$ & 131 & $46.45 \%$ & 151 & $53.55 \%$ \\
\hline
\end{tabular}

Source: The census is from Department of Household Registration Affairs, Ministry of the Interior.

\section{Results}

\subsection{Demographics}

Stratified sampling was applied to the sampling for the survey following gender and age distributions of the population between the ages of 20 to 59 in Taipei. Male respondents were accounted for $46.45 \%$ of the total valid samples. Close to $60 \%$ of respondents were married. Slightly more than $20 \%$ of respondents had educational levels of high schools or less. About $60 \%$ of respondents had college degrees, with additional $20 \%$ of respondents holding post-graduate degrees. More than one-quarter $(26.35 \%)$ of respondents had jobs in the business sector. Slightly less than $10 \%$ were in manufacturing. Respondents worked for the government, in military, or in educational institutions were accounted for $17.33 \%$. Close to $17 \%$ of respondents were housewives, and another $17 \%$ were students. The remaining respondents were in the health care industry, self-employed or currently seeking jobs. The average age of respondents was 39.59 , with average monthly personal income of USD 1,147.92 and average monthly household income of USD 3,640.02. The average household size was 3.89 persons.

\subsection{Information Received on Carbon Reduction}

In this study, information received on carbon emission reduction in various channels was investigated. As indicated in Figure 2, television was utilised by around half of the respondents in obtaining relevant information of carbon reduction, followed by newspapers, books, and magazines. Compared to other information channels, internet had been less used for searching carbon reduction information. This result indicated that some well-designed websites providing up-to-date or advanced carbon reduction information would not draw as much attention as information broadcasted in television or disseminated in printed materials. 


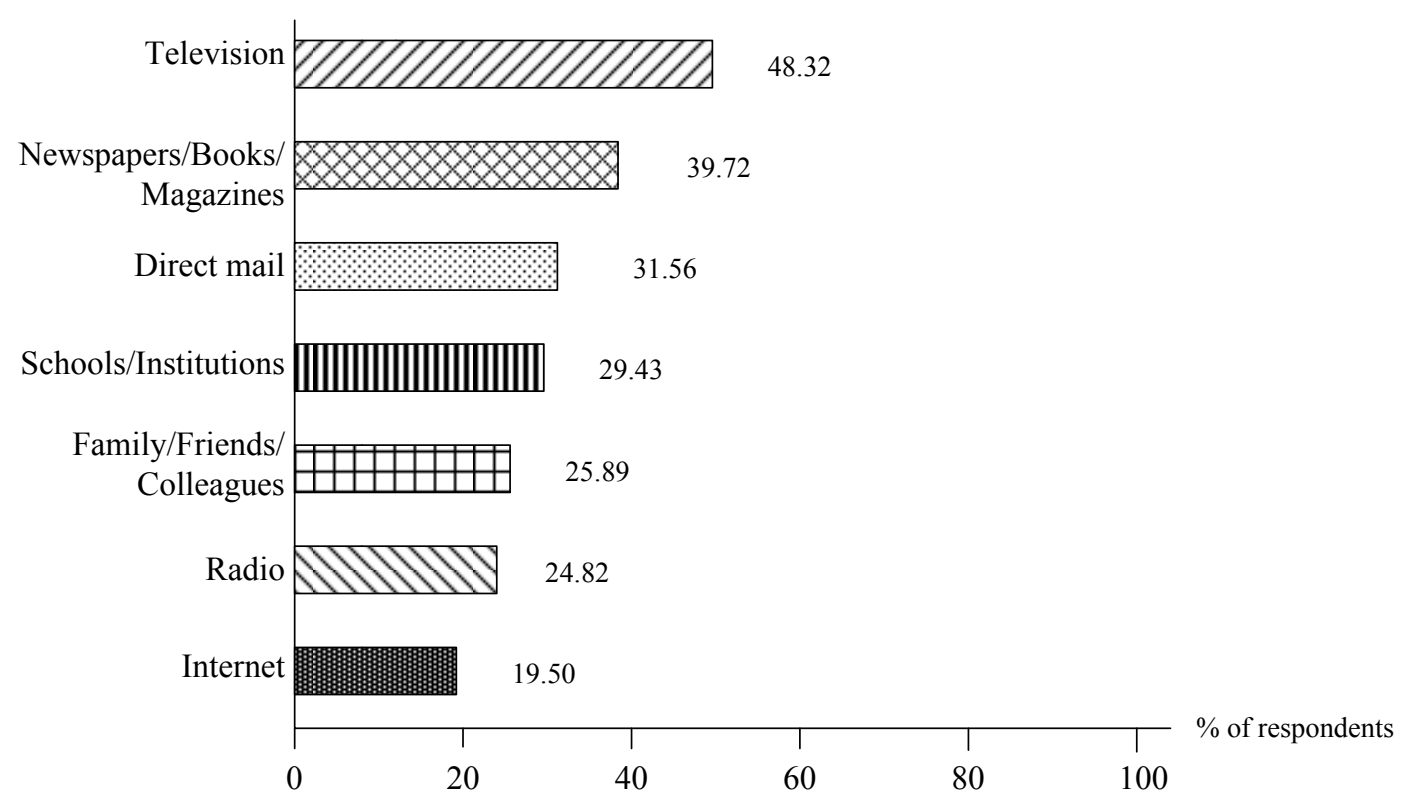

Figure 2. Sources of carbon reduction information received from various channels

Types of carbon emission reduction information respondents paid attention to are illustrated in Figure 3. Based on the results, more than $70 \%$ of respondents would have paid attention to information of practical ways of carbon reduction in daily lives, followed by information of carbon reduction policies. Carbon emissions, either from household appliances or of per capita volume would be much less interesting for respondents. For information of carbon reduction activities, only around 30\% respondents would have noticed. Hence, what people need in carbon reduction information would be mainly pragmatic.

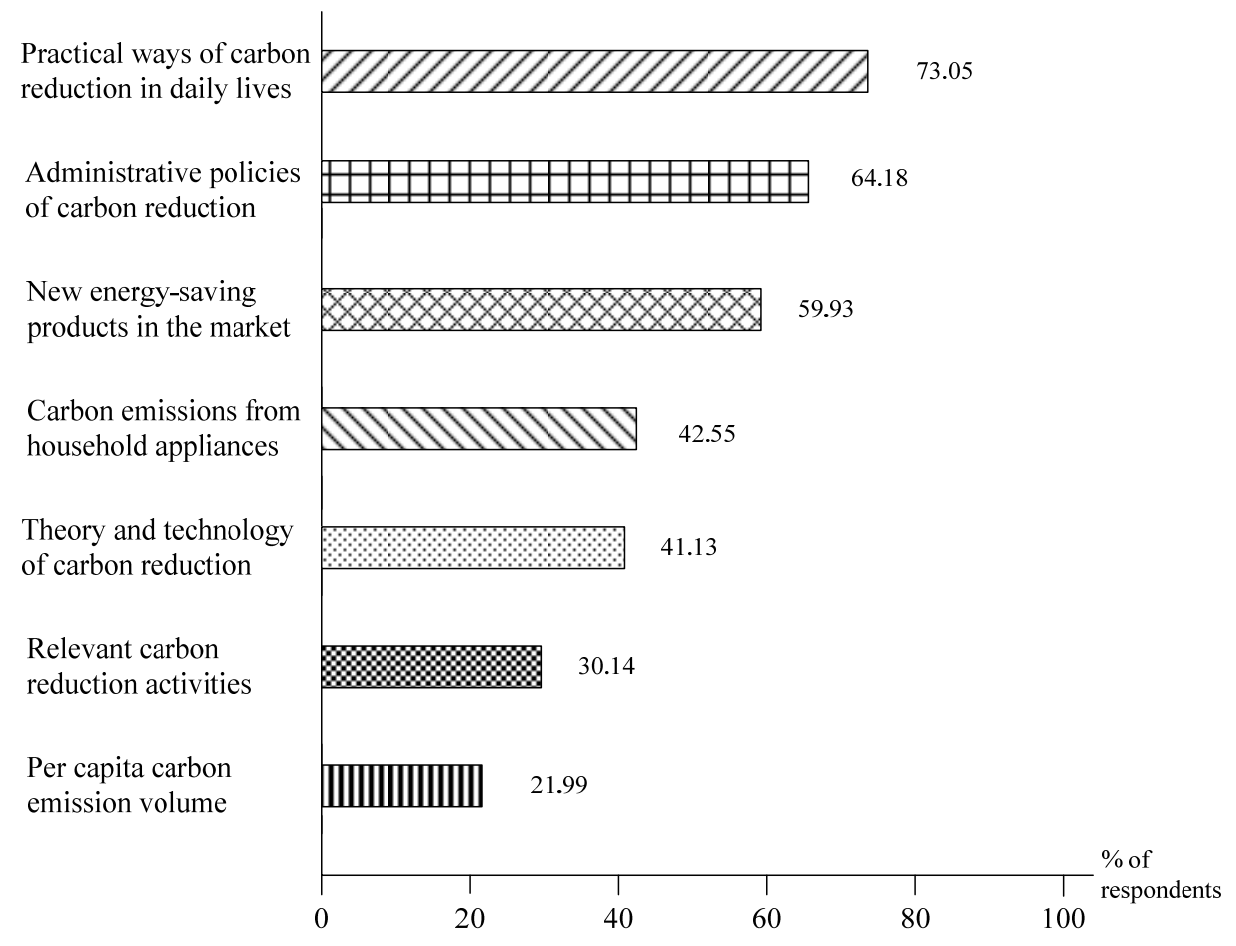

Figure 3. Types of carbon reduction information respondents paid attention to 
Respondents were asked whether they had ever encountered unrecognisable carbon reduction information. Based on the results, over $60 \%$ of respondents had some difficulties to comprehend information of carbon emission reduction they had received, mainly because the content was not relevant to daily lives or too theoretical (Figure 4). Other reasons were that carbon reduction information was too technical or too complicated. Moreover, when the content of carbon reduction information was too dry, respondents would have minimal interests in an attempt to comprehend it. This result indicates that people may not be able to understand even though they are exposed to relevant information. When respondents were asked whether they would be willing to learn more about carbon reduction, over $90 \%$ of them had shown interests. Major rationales were that carbon emission reduction was an important issue, and carbon reduction information could help them to reduce carbon emissions in daily lives. Hence, people are willing to learn more about this issue and they realise they have encountered relevant information they cannot comprehend.

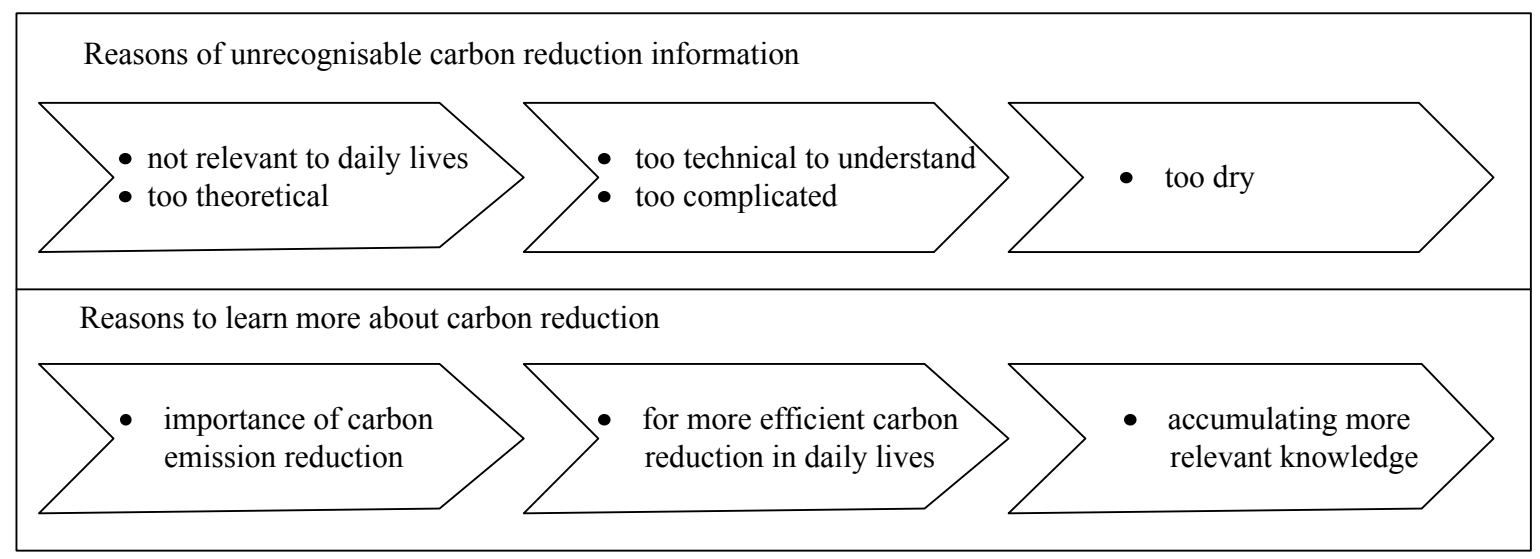

Figure 4. Encountered unrecognisable carbon reduction information and reasons to learn more

\subsection{Discrepancies in Carbon Reduction Intentions and Behaviours}

Seven types of carbon reduction information (refer to Table A1) were used in the questionnaire to reveal what respondents had searched for. The last two statements were related to theory, technology and administrative policies. These two types of carbon reduction information were considered as a foundation of the carbon reduction information and were different from other practical types of information. For those respondents who selected both statements (searching theory and technology, and policy information) in the questionnaire, they were grouped into the segment of technology/policy information seekers. Respondents in this segment cared more about fundamental issues in carbon reduction. For respondents who searched for practical carbon reduction information, they were grouped into the segment of practical information seekers. Respondents in this segment were pragmatic, mainly searching for practical type of carbon reduction information.

Regarding sources of carbon reduction information, respondents in the segment of technology/policy information seekers would be more likely to search from various channels than respondents in the segment of technology/policy information seekers would (Figure 5). Higher percentage of respondents in the segment of technology/policy information seekers would search carbon reduction information in each information channel. More than $40 \%$ of respondents in the segment of technology/policy information seekers would search carbon reduction information from schools and institutions, where less than a quarter of respondents in the segment of practical information seekers would do. Close to $30 \%$ of respondents in the segment of technology/policy information seekers would seek information on the internet, compared to about $15 \%$ of respondents in the segment of practical information seekers did. In general, technology/policy information seekers would search carbon reduction information not only from popular media but also from schools/institutions and internet which practical information seekers would pay much less attention to. 


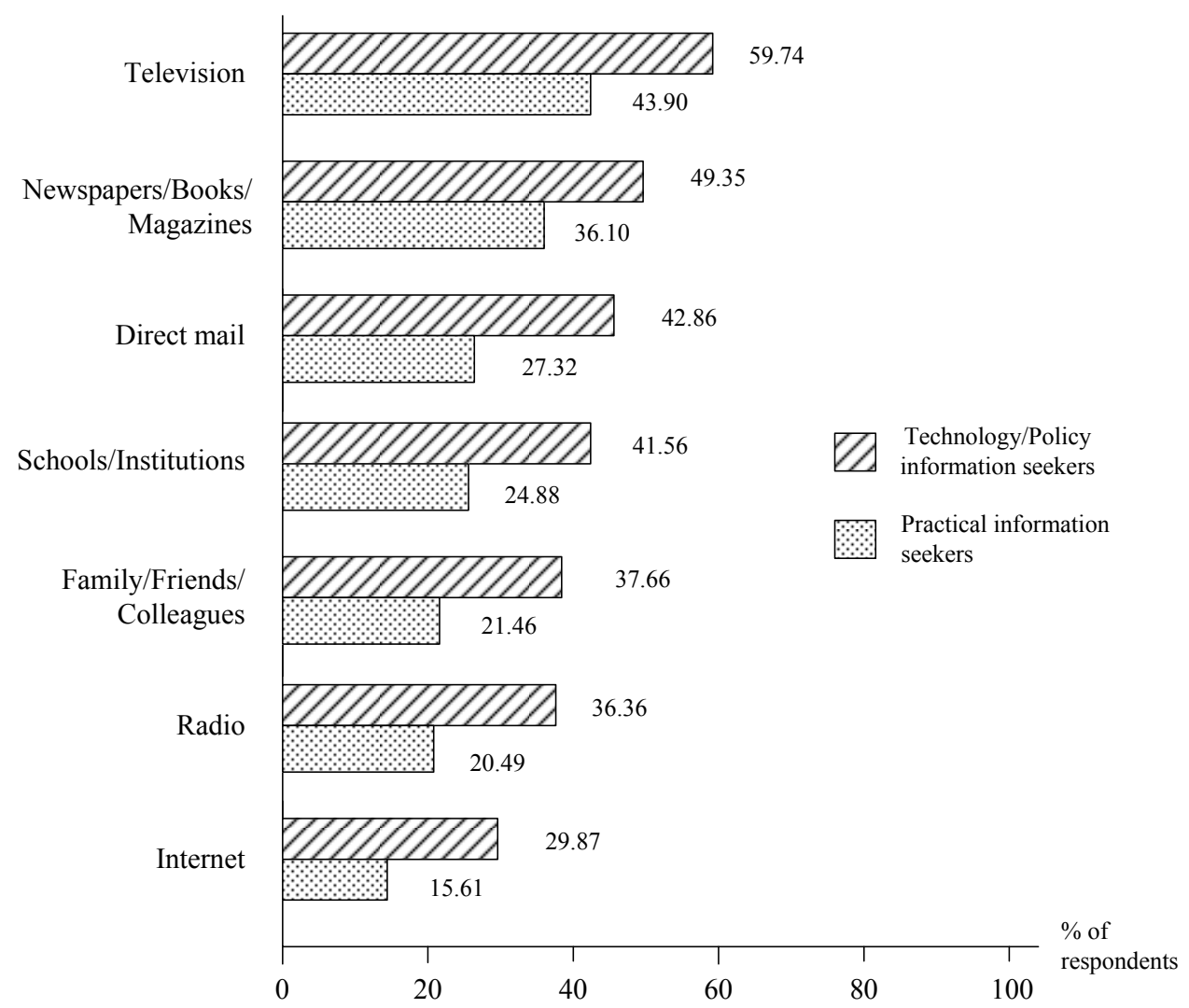

Figure 5. Sources of carbon reduction information received from various channels by segments

This study intends to quantify discrepancies in carbon reduction behaviours from intentions. Carbon reduction intentions related to what respondents thought they should be doing for environmental sustainability. Behaviours referred to actions respondents had taken in particular ways to reduce carbon emissions. Environmental behaviour discrepancies of respondents in segments of technology/policy information seekers and of practical information seekers were listed in Table 2. Five different categories, food, transportation, energy usage, reuse/recycle, and shopping activities, were used to examine behavioural discrepancies in carbon reduction.

Based on the results of this study, scores of carbon reduction intentions would be always higher than the scores of behaviours as indicated in Table 2. Discrepancies, deviations of behaviours from intentions in mean differences, would be higher for respondents in the segment of practical information seekers than those in the segment of technology/policy information seekers. This indicates that for those who were more likely to search technology and policy information of carbon reduction, they tended to act for environmental sustainability. Respondents in the segment of practical information seekers had larger gaps in discrepancies from what they thought they would be doing (intentions) to what they actually take actions (behaviours) in carbon reduction. The differences were statistically significant among respondents in these two segments in the categories of energy usage and shopping activities.

In sum, people search different types of carbon reduction information via various media channels. For those who prefer technology and policy related carbon reduction information, they would be more likely to take actions than those who prefer practical carbon reduction information. For energy usage, technology/policy information seekers would have consistent intention and behaviour. They did not just think about saving energy to reduce carbon emissions; in turn, they took actions to reduce energy usage for carbon reduction. For those who searched practical information of carbon reduction, they were prone to think more about carbon reduction than took actions. 
Table 2. Behavioural discrepancies in carbon reduction for various categories by information seeking segments

\begin{tabular}{|c|c|c|c|}
\hline Category & $\begin{array}{l}\text { Carbon reduction } \\
\text { (Means) }\end{array}$ & $\begin{array}{c}\text { Discrepancies } \\
\text { (Mean differences) }\end{array}$ & $\mathrm{t}$ test \\
\hline Food Related & & & 1.41 \\
\hline Technology/Policy information seekers & $\begin{array}{l}\text { Intention }=5.24 \\
\text { Behaviour }=4.22\end{array}$ & 1.02 & \\
\hline Practical information seekers & $\begin{array}{l}\text { Intention }=5.30 \\
\text { Behaviour }=4.11\end{array}$ & 1.19 & \\
\hline Transportation Related & & & 0.79 \\
\hline Technology/Policy information seekers & $\begin{array}{l}\text { Intention }=5.01 \\
\text { Behaviour }=4.44\end{array}$ & 0.58 & \\
\hline Practical information seekers & $\begin{array}{l}\text { Intention }=4.97 \\
\text { Behaviour }=4.30\end{array}$ & 0.68 & \\
\hline Energy Usage Related & & & $2.13^{* *}$ \\
\hline Technology/Policy information seekers & $\begin{array}{l}\text { Intention }=5.30 \\
\text { Behaviour=5.19 }\end{array}$ & 0.11 & \\
\hline Practical information seekers & $\begin{array}{l}\text { Intention }=5.28 \\
\text { Behaviour }=4.95\end{array}$ & 0.33 & \\
\hline Reuse/Recycle Related & & & 0.68 \\
\hline Technology/Policy information seekers & $\begin{array}{l}\text { Intention }=3.61 \\
\text { Behaviour }=2.81\end{array}$ & 0.79 & \\
\hline Practical information seekers & $\begin{array}{l}\text { Intention }=3.55 \\
\text { Behaviour }=2.70\end{array}$ & 0.88 & \\
\hline Shopping Related & & & $1.93^{* *}$ \\
\hline Technology/Policy information seekers & $\begin{array}{l}\text { Intention }=5.17 \\
\text { Behaviour }=4.58\end{array}$ & 0.59 & \\
\hline Practical information seekers & $\begin{array}{l}\text { Intention }=5.04 \\
\text { Behaviour }=4.23\end{array}$ & 0.80 & \\
\hline
\end{tabular}

Note: ${ }^{* *}$ indicates significance at 0.05 level.

In demographics, respondents in two segments of different types of information seekers were statistically different in gender and in education (Table 3). Close to $60 \%$ of respondents in the segment of technology/policy information seekers were males, compared to slightly more than $40 \%$ of male respondents in the segment of practical information seekers. In education, about $30 \%$ of respondents in the segment of technology/policy information seekers earned post-graduate degrees, while only $16.59 \%$ of respondents in the segment of practical information seekers did. Other demographical distributions between two segments of respondents were statistically indifferent. Hence, for those who searched for technology/policy information of carbon reduction were more likely to be males with higher educational levels. Females would prefer practical information of carbon reduction. 
Table 3. Demographics of respondents by information seeking segments

\begin{tabular}{|c|c|c|c|}
\hline & $\begin{array}{c}\text { Technology/Policy } \\
(\mathrm{n}=77)\end{array}$ & $\begin{array}{l}\text { Practical } \\
(n=205)\end{array}$ & Tests \\
\hline Gender (\%) & & & $\chi^{2}=7.52^{* *}$ \\
\hline Male & 59.74 & 41.46 & \\
\hline Female & 40.26 & 58.54 & \\
\hline Marriage ( $\%$ of married) & 62.34 & 58.05 & $\chi^{2}=0.43$ \\
\hline Average age (years) & 41.16 & 39.00 & $\mathrm{t}=-1.3$ \\
\hline Educational level (\%) & & & $\chi^{2}=8.68^{*}$ \\
\hline Elementary school & 1.30 & 0.49 & \\
\hline Junior high school & 2.60 & 0.98 & \\
\hline Senior high school & 12.99 & 20.00 & \\
\hline College & 53.24 & 61.94 & \\
\hline Graduate school & 29.87 & 16.59 & \\
\hline Occupation (\%) & & & $\chi^{2}=0.84$ \\
\hline Public/Military/Education & 18.67 & 16.83 & \\
\hline Manufacture & 9.33 & 9.40 & \\
\hline Business & 24.00 & 27.23 & \\
\hline Housewives & 17.33 & 16.34 & \\
\hline Students & 18.67 & 15.84 & \\
\hline Others & 12.00 & 14.36 & \\
\hline Average personal income (USD/month) & 1158.97 & 1143.77 & $\mathrm{t}=-0.13$ \\
\hline Average household income (USD/month) & 2864.36 & 2556.84 & $\mathrm{t}=-1.50$ \\
\hline Average household size (persons) & 3.82 & 3.92 & $\mathrm{t}=0.56$ \\
\hline
\end{tabular}

Note: ${ }^{* * *}$ indicates significance at 0.01 level $;{ }^{*}$ indicates significance at 0.1 level.

\section{Discussion}

Increases in the concentration of carbon dioxide in the atmosphere had caused rising in the global temperature and occurrence of the extreme weather. Effectiveness in information dissemination to increase environmental awareness and to encourage carbon reduction behaviours is an urgent issue. In this study, carbon reduction information search and behavioural discrepancies in carbon reduction were examined.

In information search, television was the most common channel for respondents to obtain carbon emission reduction information, followed by newspapers, magazines and books. Internet was more likely to be used by technology/policy information seekers, but less by practical information seekers. Information contents related to carbon reduction in daily lives and carbon reduction policies could draw more attention. However, respondents were not interested in information of per capita carbon emission volume, which was of importance in terms of the severity of this matter in Taiwan. More than half of respondents had encountered some carbon reduction information which they could not comprehend, while the majority of respondents would be willing to learn more about this issue.

Behavioural discrepancies in carbon reduction were analysed in this study. Technology/policy information seekers would have carbon reduction behaviours similar to their intentions, especially in energy usage and shopping activities. Practical information seekers seem to have higher level of discrepancies in carbon reduction, with a greater extent of deviation in behaviours from intentions.

The findings in this study contribute information for policy makers and administrative agencies. Implications based on the results of this study are suggested as follows.

1) The empirical results revealed that respondents paid less attention to the information of detailed per capita carbon emission volume. Through dissemination of this factual emission figure to educate the general public, people may be better informed about the severity of this matter in Taiwan and are motivated to be more environmentally sustainable in behavioural decisions.

2) Some respondents had difficulties to comprehend carbon reduction information. Clear descriptions of carbon reduction information should be applied to ease the difficulties in understanding relevant knowledge of carbon reduction. 
3) For the general public, people seek different types of carbon reduction information. Technology/policy information seekers would be those with higher education levels and were more likely to be males. Females would be more interested in practical information in carbon reduction. Hence, technological and policy type of carbon reduction information could be disseminated on internet where technology/policy information seekers tend to use for information search. Practical carbon reduction information could be disseminated on television and in newspapers, books, and magazines.

4) Practical information seekers tend to have larger discrepancies between carbon reduction intentions and behaviours than technical/policy information seekers have. In educating the general public, encouraging actions of carbon reduction behaviours is important. Only when people realise they need to take actions as much as they think they should do, the severity of carbon emissions could be lessened. In the literature, Tobler et al. (2012) emphasised the importance of providing action-related knowledge to the general public so people would sense the contribution of personal behaviours in carbon reduction to the issue of climate change.

Bravo et al. (2013) stated that behavioural transition towards environmentally sustainable condition strongly relied on individuals' willingness to adopt best possible practices. Information disseminated for public education encouraging environmentally sustainable behaviours can be more effective in carbon reduction than simply exemplifying the circumstances of global warming for awareness. This study examines information of carbon reduction individuals search and behavioural discrepancies of carbon reduction to reveal the existence of 'value-action gap' as explained in Pickett-Baker and Ozaki (2008). Limitation of this study is that the sampling frame was only based on population in a metropolitan area in Taipei, Taiwan. Future studies may need to include survey respondents from urban and rural areas to reveal behavioural differences in carbon reduction based on divergent regional development.

\section{Acknowledgements}

This study is partially supported by National Science Council (NSC 97-2515-S-005-003-SC).

\section{References}

Animal Benefits Association, Taiwan. (2011, September 12). Earth-saving carbon reduction fair in Da An Park. Retrieved from http://www.dog99.org.tw/news.htm

Arlt, D., Hoppe, I., \& Wolling, J. (2011). Climate change and media usage: Effects on problem awareness and behavioural intentions. International Communication Gazette, 73(1-2), 45-63. http://dx.doi.org/10.1177/1748048510386741

Arslan, T., Yilmaz, V., \& Aksoy, H. K. (2012). Structural equation model for environmentally conscious purchasing behaviour. International Journal of Environmental Research, 6(1), 323-334.

Bord, R. J., O'Connor, R. E., \& Fisher, A. (2000). In what sense does the public need to understand global climate change? Public Understanding of Science, 9(3), 205-218. http://dx.doi.org/10.1088/0963-6625/9/3/301

Bravo, G., Vallino, E., Cerutti, A. K., \& Pairotti, M. B. (2013), Alternative scenarios of green consumption in Italy: An empirically grounded model. Environmental Modelling and Software, 47, 225-234. http://dx.doi.org/10.1016/j.envsoft.2013.05.015

Bureau of Energy, Ministry of Economic Affairs, Taiwan. Carbon reduction 520-Ministry of Economic Affairs, Five new policies for saving energy and carbon reduction. Retrieved from http://blog.roodo.com/sevenyeh/archives/9106843.html

Buy Green, Taiwan. Retrieved from http://www.buygreentw.net/search.aspx?c=6

Chan, K. K. W. (1999). Mass media and environmental knowledge of secondary school students in Hong Kong. The Environmentalist, 19(2), 85-97. http://dx.doi.org/10.1023/A:1006636832732

Department of Household Registration Affairs, Ministry of the Interior. Taiwan. Retrieved from http://www.ris.gov.tw/home;jsessionid=862ED44076E44074957BFE7801E8DA8A

EcoLife, Environmental Protection Administration Executive Yuan, Taiwan. Big action. Retrieved from http://ecolife.epa.gov.tw/Cooler/BigAction_item.aspx

EcoLife, Environmental Protection Administration Executive Yuan, Taiwan. $\mathrm{CO}_{2}$ emission calculation from household appliances. $\mathrm{CO}_{2}$ reduction methods for citizens, p. 51. Retrieved from http://ecolife.epa.gov.tw/Cooler/download.aspx\#E 
EcoLife, Environmental Protection Administration Executive Yuan, Taiwan. Methods of carbon reduction. Retrieved from http://ecolife.epa.gov.tw/Cooler/download.aspx\#G

Energy Star, United States. Find energy star products. Retrieved from http://www.energystar.gov/index.cfm?c=products.pr_find_es_products

Environmental Protection Administration Executive Yuan, Republic of China. Policies for energy saving and carbon reduction. Retrieved from http://www.epa.gov.tw/ch/aioshow.aspx?busin=12379\&path=12403\&guid=3c1ee813-33d2-4c79-9579-834 c089dd983\&lang=zh-tw

Environmental Protection Agency, United States. Climate change, what you can do. Retrieved from http://epa.gov/climatechange/wycd/index.html

Hansen, P. J. K. (2010). Knowledge about the greenhouse effect and the effects of the ozone layer among Norwegian pupils finishing compulsory education in 1989, 1993, and 2005-what now? International Journal of Science Education, 32(3), 397-419. http://dx.doi.org/10.1080/09500690802600787

Intergovernmental Panel on Climate Change, Fourth assessment report, synthesis report, climate change. (2007). Retrieved from http://www.ipcc.ch/pdf/assessment-report/ar4/syr/ar4_syr.pdf

International Energy Agency. $\mathrm{CO}_{2}$ emissions from fuel combustion highlights. (2012). Retrieved from http://www.iea.org/publications/freepublications/publication/name,4010,en.html

Kalantari, Kh., \& Asadi, A. (2010). Designing a structural model for explaining environmental attitude and behavior of urban residents (case of Tehran). International Journal of Environmental Research, 4(2), 309-320.

Knowledge Center, Energy Park, Taiwan. Saving energy in daily lives. Retrieved from $\mathrm{http}: / /$ www.energypark.org.tw/news/knowledge/listlevel.asp?mId=15\&CategoryId=48\&sId=126

Nisbet, M. C., Scheufele, D. A., Shanahan, J., Moy, P., Brossard, D., \& Lewenstein, B. V. (2002). Knowledge, reservations, or promise? A media effects model for public perception of science and technology. Communication Research, 29(5), 584-608. http://dx.doi.org/10.1177/009365002236196

Peter, M. (2009, March). Saving energy, it starts at home. National Geographic, 99, 2-7. Retrieved from http://ngm.nationalgeographic.com/2009/03/energy-conservation/miller-text/1

Pickett-Baker, J., \& Ozaki, R. (2008). Pro-environmental products: Marketing influence on consumer purchase decision. Journal of Consumer Marketing, 25(5), 281-293. http://dx.doi.org/10.1108/07363760810890516

Robson, A., \& Robinson, L. (2013). Building on models of information behaviour: Linking information seeking $\begin{array}{llll}\text { and } & \text { communication. Journal of }\end{array}$ http://dx.doi.org/10.1108/00220411311300039

Stamm, K. R., Clark, F., \& Eblacas, P. R. (2000). Mass communication and public understanding of environmental problems: the case of global warming. Public Understanding of Science, 9(3), 219-237. http://dx.doi.org/10.1088/0963-6625/9/3/302

Sufiyan, A. M. (2013). Initiatives of global cities in environmental sustainability: A case of London and New York City. Journal of Sustainable Development, 6(3), 1-15. http://dx.doi.org/10.5539/jsd.v6n3p1

Tobler, C., Visschers, V. H. M., \& Siegrist, M. (2012). Consumers' knowledge about climate change. Climate Change, 114(2), 189-209. http://dx.doi.org/10.1007/s10584-011-0393-1

Tukker, A., Huppes, G., Guniée, J., Heijungs, R., de Koning, A., van Oers, L., ... Delgado, L., (2006). Environmental Impact of Products (EIPRO), Technical Report EUR 22284 EN, European Commission Joint Research Centre. Retrieved from http://ec.europa.eu/environment/ipp/pdf/eipro_report.pdf

Whitmarsh, L., \& O'Neill, S. (2010). Green identity, green living? The role of pro-environmental self-identity in determining consistency across diverse pro-environmental behaviours. Journal of Environmental Psychology, 30(3), 305-314. http://dx.doi.org/10.1016/j.jenvp.2010.01.003

Zhang, Y. G. (2009). Bangkok climate change talks. Retrieved from http://blog.chinatimes.com/lowestc/archive/2009/10/08/439571.html 


\section{Appendix}

Table A1. Sources of various types of carbon reduction information

\begin{tabular}{|c|c|c|}
\hline \multicolumn{2}{|r|}{ Information type } & Sources \\
\hline 1) & $\begin{array}{l}\text { Practical ways of carbon reduction in daily } \\
\text { lives }\end{array}$ & 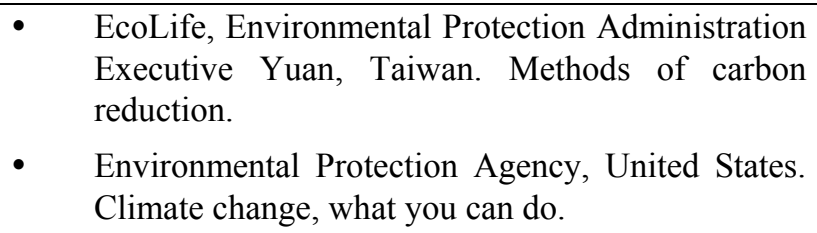 \\
\hline 2) & New energy-saving products in the market & $\begin{array}{l}\text { - Buy Green, Taiwan } \\
\text { - Energy Star, United States. Find energy star } \\
\text { products. }\end{array}$ \\
\hline 3) & Per capita carbon emission volume & $\begin{array}{l}\text { - Zhang, Y. G. (2009). Bangkok climate change } \\
\text { talks. }\end{array}$ \\
\hline 4) & $\begin{array}{l}\text { Carbon emissions from household } \\
\text { appliances }\end{array}$ & $\begin{array}{l}\text { - Peter, M. (March, 2009) Saving energy, it starts at } \\
\text { home. National Geographic. } \\
\text { EcoLife, Environmental Protection Administration } \\
\text { Executive Yuan, Taiwan. } \mathrm{CO}_{2} \text { emission } \\
\text { calculation from household appliances. } \mathrm{CO}_{2} \\
\text { reduction methods for citizens. }\end{array}$ \\
\hline 5) & Relevant carbon reduction activities & $\begin{array}{l}\text { - Animal Benefits Association, Taiwan. } \\
\text { Earth-saving carbon reduction fair in Da An Park. } \\
\text { EcoLife, Environmental Protection Administration } \\
\text { Executive Yuan, Taiwan. Big action. }\end{array}$ \\
\hline 6) & Theory and technology of carbon reduction & $\begin{array}{l}\text { - Knowledge Center, Energy Park, Taiwan. Saving } \\
\text { energy in daily lives. }\end{array}$ \\
\hline 7) & Administrative policies of carbon reduction & $\begin{array}{l}\text { - Bureau of Energy, Ministry of Economic Affairs, } \\
\text { Taiwan. Carbon reduction 520-Ministry of } \\
\text { Economic Affairs, Five new policies for saving } \\
\text { energy and carbon reduction. }\end{array}$ \\
\hline & & $\begin{array}{l}\text { Environmental Protection Administration } \\
\text { Executive Yuan, Republic of China. Policies for } \\
\text { energy saving and carbon reduction. }\end{array}$ \\
\hline
\end{tabular}


Table A2. Statements of carbon reduction intentions and behaviours in the questionnaire

Statements of carbon reduction intentions

1) I believe food should not be wasted.

2) I believe I should be eating more vegetables and less meat.

3) I believe walking or cycling should be used to replace driving or riding motorcycles.

4) I believe I should take public transportation if available.

5) I believe I should turn off air conditioners more often and open up windows to help air circulations.

6) I believe I should turn off power switch of unused appliances.

7) I believe reuse/recycle should be a must.

8) I believe I should use less disposable products (like disposable bamboo chopsticks and plastic utensils).

9) I believe I should purchase fewer clothes.

10) I believe I should purchase appliances with certificates of energy efficiency.

Statements of carbon reduction behaviours

1) When I have a dinner with friends in restaurants, I order just about the right amount of food items instead of ordering more than enough.

2) I have at least one day a week without eating meat products.

3) If the distance of a destination can be reached by foot or by bicycle, then I choose not to drive or to ride motorcycles.

4) I am willing to take public transportations.

5) When the room temperature is not above 28 centigrade, I do not turn on air conditioners.

6) I turn off the light whenever I leave the room.

7) I choose rechargeable batteries.

8) I carry personal chopsticks (like travel sets), water bottles, and reusable shopping bags with me.

9) I do not shop for clothing as long as I have enough.

10) When I purchase appliances, I choose those certified with energy efficiency labels.

\section{Copyrights}

Copyright for this article is retained by the author(s), with first publication rights granted to the journal.

This is an open-access article distributed under the terms and conditions of the Creative Commons Attribution license (http://creativecommons.org/licenses/by/3.0/). 